\title{
Park kulturowy jako forma ochrony dziedzictwa kulturowego. Doświadczenia gmin Dolnego Śląska
}

\#dziedzictwo kulturowe \#zabytek \#krajobraz \#ochrona krajobrazu \#krajobraz kulturowy \#park kulturowy \#samorzad terytorialny \#gmina \#cultural heritage \#monument \#landscape \#landscape protection \#cultural landscape \#culture park \#local self-government \#commune

Park kulturowy jest jedną z form ochrony zabytków. Przedmiotem ochrony jest w tym wypadku krajobraz kulturowy, czyli przestrzeń zawierająca elementy przyrodnicze i wytwory cywilizacji, historycznie ukształtowana w wyniku czynników naturalnych i działania człowieka. Wyłączną kompetencję do tworzenia parków kulturowych mają gminy. Jednak mimo dużej swobody w tym zakresie ta forma ochrony krajobrazu nie stała się powszechna, czego wyrazem jest niewielka liczba parków kulturowych w Polsce. Na Dolnym Śląsku są jedynie cztery takie obszary. Analiza procesu tworzenia parków i ich funkcjonowania pokazuje, że zarządzanie krajobrazem w postaci parku kulturowego nie spełnia oczekiwań. Sytuację zmienić może wejście w życie ustawy krajobrazowej, która służyć ma m.in. uporządkowaniu chaosu przestrzennego i nadmiaru reklamy w przestrzeni publicznej.

Culture park is a form of monument protection. The object of protection is in this case the cultural landscape, or space containing natural elements and products of civilization, historically shaped by natural factors and human activity. Communes have the exclusive competence to establish and create culture parks. However, despite the considerable freedom in this area, this form of landscape protection has not become widespread, which is reflected in the small number of culture parks in Poland. There are only four such areas in Lower Silesia. The analysis of the park creation process and their functioning shows that managing landscape in the form of a culture park does not meet expectations. This situation may be changed by passing the Landscape Act, aiming at_-among others_-rearranging the spatial chaos and excess advertising in public space.

Miasto. Pamięć i Przyszłość 1 (2017) ISSN 2543-621X

\section{OPEN ACCESS}

Citation: Pawłowska A., Culture park as a form of protection of cultural heritage. The experience of the Lower Silesia's communes, "Miasto. Pamięć i Przyszłość: Wrocławski Rocznik Samorządowy" - No 1 https://doi.org/10.xxxxx

Editor: Katarzyna Uczkiewicz Received: October, 2016 Accepted: December, 2016

Published: December, 2016

Copyright: @ Ośrodek „Pamięć i Przyszłość" This is an open access article distributed under the terms of the Creative Commons Attribution-ShareAlike Licence, which permits unrestricted use, distribution, and reproduction in any medium, provided the original author and source are credited, with indications if any changes are made. All derivative works must be licensed under the same licence.

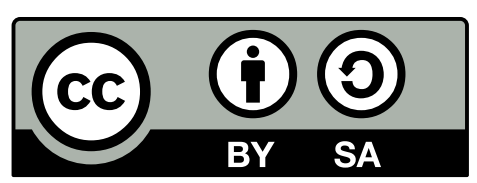




\section{Park kulturowy jako forma ochrony dziedzictwa kulturowego. Doświadczenia gmin Dolnego Śląska}

Dziedzictwo kulturowe stanowi szczególny zasób wspólnot lokalnych, regionów, państw czy wreszcie całej ludzkości. Jednak nie zawsze postrzegane bywa jako czynnik rozwoju. Ochrona poszczególnych elementów dziedzictwa wiąże się bowiem z szeregiem ograniczeń, a niekiedy uznawana jest za przeszkodę w planowaniu i zarządzaniu przestrzenią oraz utrudnienie w kreowaniu warunków rozwoju ekonomicznego i społecznego. Z czasem ta perspektywa ulegała modyfikacji i obecnie dziedzictwo kulturowe traktować trzeba nie tylko jako ważny element tożsamości i czynnik integracji społecznej, ale również jako istotny potencjał gospodarczy. Należy przy tym pamiętać, że zachowanie najcenniejszych obiektów dziedzictwa jest nie tylko sprawą ich właścicieli, samorządów czy państw; dziedzictwo stanowi dobro całej ludzkości'.

\section{Ochrona krajobrazu jako elementu dziedzictwa kulturowego}

Termin „dziedzictwo kulturowe” jest trudny do jednoznacznego zdefiniowania. Dyskusje budzi już samo zastosowanie przymiotnika

Miasto. Pamięć i Przyszłość 1 (2016) ISSN 2543-621X "kulturowy"2. Dodatkowym utrudnieniem jest wielość pojęć obejmujących swoim znaczeniem zagadnienia odnoszące się do dziedzictwa, takich jak: dobro kultury, dziedzictwo kultury, dziedzictwo kulturalne, dziedzictwo kulturowe czy zabytek. Bogactwo definicyjne bywa jednak postrzegane pozytywnie, jako świadectwo tego, jak ważne dla współczesnych społeczeństw są kwestie związane z ochroną zabytków, dziedzictwem, kulturą3. Mimo tych dyskusji można przyjąć, że dziedzictwo kulturowe to „zasób rzeczy nieruchomych i ruchomych wraz ze związanymi z nimi wartościami duchowymi, zjawiskami historycznymi i obyczajowymi uznawany za godny ochrony prawnej dla dobra społeczeństwa i jego rozwoju oraz przekazania następnym pokoleniom, z uwagi na wartości historyczne, patriotyczne, religijne, naukowe i artystyczne, mające

1. A. Przyborowska-Klimczak, Rozwój ochrony dziedzictwa kulturalnego w prawie międzynarodowym na przełomie XX i XXI wieku, Lublin 2011, s. 10.

2. W literaturze stosuje się niekiedy zamiennie niesynonimiczne terminy: „dziedzictwo kulturowe” (K. Pawłowska), „dziedzictwo kulturalne” (J. Pruszyński i A. Przyborowska-Klimczak), „dziedzictwo kultury" (K. Zeidler). Na potrzeby artykułu, nie tylko przez analogię do nazwy "park kulturowy”, wybrano określenie dziedzictwo kulturowe.

3. M. Rouba, Zadania władz publicznych w zakresie ochrony i opieki nad zabytkami w Rzeczypospolitej Polskiej, Toruń 2013, s. 22. 
znaczenie dla tożsamości i ciągłości rozwoju" ${ }^{\prime \prime}$. Pierwsze dokumenty o charakterze międzynarodowym odnoszące się do prawnej ochrony dziedzictwa kulturowego czy dóbr kultury pojawiły się w XIX w. Towarzyszyły one podpisywaniu traktatów pokojowych i dotyczyły poszanowania dziedzictwa kulturowego w sytuacji konfliktów zbrojnych, gdyż historycznie patrząc, początkowo prawo chroniło dobra kultury na wypadek wojny ${ }^{5}$. Obecnie regulacje traktatowe o zasiągu globalnym i regionalnym są bardzo rozbudowane i obejmują różne rodzaje dziedzictwa: dziedzictwo przyrodnicze i kulturowe, dziedzictwo materialne i niematerialne, dobra o charakterze ruchomym i nieruchomym, w tym krajobraz kulturowy, dziedzictwo archeologiczne, podwodne czy dziedzictwo cyfrowe.

Wśród obiektów dziedzictwa podlegających ochronie, czy to na gruncie prawa międzynarodowego czy krajowego, wymienia się krajobraz. Krajobraz jest pojęciem wieloznacznym. Najczęściej tym terminem określa się część powierzchni widzianą z konkretnego miejsca. Sens tego 4. J. Pruszyński, Dziedzictwo kultury Polski. Jego straty i ochrona
prawna, T. 1, Zakamycze 2001, s. 50.

5. A. Przyborowska-Klimczak, op. cit., s. 18, L. Łukaszuk, Międzynarodowa ochrona dóbr kultury, [w:] Prawna ochrona dóbr kultury, red. T. Gardocka, J. Sobczak, Toruń 2009, s. 44, K. Pawłowska, M. Swaryczewska, Ochrona dziedzictwa kulturowego. Zarzq̨dzanie i partycypacja społeczna, Kraków 2002, s. 15.

6. D. Kostrzewa, Krajobraz przyrodniczy a krajobraz kulturowy - porównanie instytucji prawnych, [w:] Ochrona dziedzictwa kulturowego i naturalnego. Perspektywa prawna i kryminologiczna, red. W. Pływaczewski, B. Gadecki, Warszawa 2015, s. 55-56.

7. R. M. Łuczyński, P. Migoń, P. Napierała, Krajobraz kulturowy regionu Kotliny Jeleniogórskiej, Wrocław 2015, s. 1.

8. Leksykon prawa ochrony zabytków, red. K. Zeidler, Warszawa 2010, s. 142-143.

9. Przyjęta w Paryżu 16 listopada 1972 r. przez Konferencję Generalną Organizacji Narodów Zjednoczonych dla Wychowania, Nauki i Kultury (UNESCO) (Dz. U. z 1976r. Nr 190, poz. 32). pojęcia ewoluował w czasie. Liczne trudności definicyjne wynikające z niejednoznacznego definiowania krajobrazu skutkują problemami z prawnym uregulowaniem zakresu jego ochrony ${ }^{6}$. Krajobraz najczęściej wiązany jest z naturą i przyrodą, ale stan naturalny ulegał i ulega przekształceniom wszędzie, gdzie żyje i działa człowiek. Skala ingerencji człowieka w otoczenie spowodowała, że w ostatnich latach zaobserwować można wzrost zainteresowania problematyką ochrony krajobrazu, a sam krajobraz stał się wyjątkowym dobrem, które ma duże znaczenie dla jednostek i społeczności. Wyrazem ewolucji podejścia do krajobrazu jest m.in. jego miejsce w zbiorze najważniejszych wartości współczesnej polityki europejskiej. ${ }^{7}$ Krajobraz stanowi ważny element życia zarówno w małych gminach, jak i dużych aglomeracjach. W miastach historycznych staje się ważnym zasobem i narzędziem rozwoju, które wymaga ochrony.

Najogólniej wskazuje się na trzy rodzaje krajobrazu: krajobraz naturalny (pierwotny) wolny od śladów działalności człowieka, krajobraz zurbanizowany oraz krajobraz kulturowy (antropogeniczny) - zagospodarowany przez człowiekå. Podział krajobrazu na przyrodniczy i kulturowy utrwalał się przez lata, a przyczynił się do tego również najważniejszy dokument prawa międzynarodowego regulujący kwestie ochrony dziedzictwa, czyli Konwencja UNESCO w sprawie ochrony światowego dziedzictwa kulturalnego i naturalnego z 1972 r. ${ }^{9}$. Wśród obiektów, które mogły zostać objęte wpisem na Listę Światowego Dziedzictwa, umieszczono obiekty

Miasto. Pamięć i Przyszłość 1 (2016) ISSN 2543-621X 
„krajobrazowe”, ale odrębnie te o charakterze naturalnym i kulturowym. Dopiero w 1992 r. nastąpiła korekta w postrzeganiu krajobrazu jako obiektu podlegającego ochronie i uznano krajobraz kulturowy za osobną grupę dóbr ${ }^{10}$.

Choć problematyce ochrony krajobrazu poświęcono wiele publikacji i dokumentów międzynarodowych ${ }^{11} \mathrm{w}$ polskim ustawodawstwie definicja krajobrazu pojawiła się dopiero w 2015 r. w ustawie o zmianie niektórych ustaw w związku ze wzmocnieniem narzędzi ochrony krajobrazu12, nazywanej powszechnie ustawą krajobrazową. Ustawa krajobrazowa, nowelizując m.in. ustawę o planowaniu i zagospodarowaniu przestrzennym, wprowadza do porządku prawnego pojęcie krajobrazu rozumianego jako „postrzegana przez ludzi przestrzeń, zawierająca elementy przyrodnicze lub wytwory cywilizacji, ukształtowana w wyniku działania czynników naturalnych lub działalności człowieka"13. Zapis ten jest realizacją postanowień Europejskiej Konwencji Krajobrazowej ${ }^{14}$ ratyfikowanej przez Polskę w 2004 r.

Europejska Konwencja Krajobrazowa, przyjęta przez Radę Europy w 2000 r., jest najważniejszym europejskim dokumentem regulującym kwestie ochrony krajobrazu. W preambule do konwencji wskazano m.in., że krajobraz pełni ważną rolę w tworzeniu kultur lokalnych oraz jest podstawowym komponentem europejskiego dziedzictwa przyrodniczego i kulturowego. Krajobraz jako istotna część jakości życia ludzi zamieszkujących wszędzie: w obszarach miejskich i na wsi, na obszarach zdegradowanych,

Miasto. Pamięć i Przyszłość 1 (2016) ISSN 2543-621X 87 jak również w obszarach o wysokiej jakości, staje się kluczowym elementem dobrobytu całości społeczeństwa i jednostek. Dlatego jego ochrona, rozumiana jako działania na rzecz zachowania i utrzymywania ważnych i charakterystycznych cech krajobrazu, których celem jest ukierunkowanie oraz harmonizowanie zmian wynikających z procesów społecznych, gospodarczych i środowiskowych, a także gospodarka i planowanie w tym zakresie niesie w sobie prawa i obowiązki dla każdego człowieka. Konwencja w art. 5 zobowiązuje państwa, będące stroną konwencji, do prawnego uznania krajobrazów jako istotnego komponentu otoczenia ludzi, wyrażającego różnorodność kulturową i przyrodniczą oraz stanowiącego podstawę ich tożsamości; ustanowienia i wdrożenia polityki w zakresie krajobrazu; ustanowienia procedur udziału społeczeństwa, organów lokalnych i regionalnych oraz innych stron zainteresowanych w procesie kształtowania polityki w zakresie krajobrazu; zintegrowania krajobrazu z polityką w zakresie planowania regionalnego i urbanistycznego i polityką kulturalną, środowiskową,

10. Konwencje UNESCO w dziedzinie kultury. Komentarz, red. K. Zalasińska, Warszawa 2014, s. 252.

11. Są to prócz wcześniej wskazanej Konwencji UNESCO np. Zalecenia UNESCO dotyczące ochrony piękna i charakteru krajobrazów i miejsc (1962), Zalecenia UNESCO dotyczące ochrony i współczesnej roli obszarów historycznych (1976), zob. M. Rouba, op. cit., s. 61, Zalecenia UNESCO w sprawie historycznego krajobrazu miejskiego (2011), http://www.unesco.pl/fileadmin/user_upload/ pdf/Rekomendacje/Zalecenie_w_sprawie_krajobrazu_miejskiego. pdf (dostęp: 14 VIII 2016).

12. Ustawa z dnia 24 kwietnia 2015 o zmianie niektórych ustaw w związku ze wzmocnieniem narzędzi ochrony krajobrazu (Dz. U. poz. 774, z póżn. zm.).

13. Ustawa z dnia 23 marca 2003 r. o planowaniu i zagospodarowaniu przestrzennym (tekst jedn. Dz. U. z 2016 r. poz. 778), art. 2 ust. $16 \mathrm{e}$.

14. Europejska Konwencja Krajobrazowa sporządzona we Florencji 20 października 2000 r. (Dz. U. z 2004 r. Nr 14, poz. 98). 
społeczną i gospodarczą, jak również z innymi oddziałującymi na krajobraz.

Konwencja nie oddziela krajobrazu przyrodniczego od kulturowego, stąd w działaniach na rzecz ochrony krajobrazu należy postrzegać go jako całość. Ponadto wdrożenie jej zapisów następować ma w zgodzie z zasadami konstytucyjnymi i organizacją administracyjną właściwą poszczególnym krajom, z zaznaczeniem roli zasady subsydiarności i uwzględnieniem Europejskiej Karty Samorządu Lokalnego ${ }^{15}$ (art. 4). Implikuje to istotną rolę jednostek samorządu terytorialnego w tworzeniu i realizowaniu polityki ochrony krajobrazu.

\section{Zadania samorządu gminnego w ochronie dziedzictwa kulturowego}

Zgodnie z art. 164 Konstytucji RP gmina stanowi podstawową jednostkę samorządu ${ }^{16}$. Gminę tworzą mieszkańcy i zamieszkane przez nich terytorium ${ }^{17}$. Choć powstaje z mocy prawa i obecność faktycznych więzi tworzących wspólnotę nie jest elementem koniecznym do jej utworzenia, to jej prawidłowe funkcjonowanie opiera się na odpowiednio ukształtowanych relacjach społecznych i związku z zajmowaną przestrzenią.

Przestrzeń, w której funkcjonują wspólnoty lokalne, jest mieszanką składników naturalnych i kulturowych stanowiących łącznie dobro publiczne, szczególną wartość czy wyjątkowy zasób. Bez względu na skalę i znaczenie poszczególnych

15. Europejska Karta Samorządu Lokalnego (Dz. U. z 1994, Nr 124, poz. 607)

16. Konstytucja RP z dnia 12 kwietnia 1997 r. (Dz. U. Nr 78, poz. 483).

17. Ustawa z dnia 8 marca 1990 r. o samorządzie gminnym, art. 1 , (tekst jedn. Dz. U. z 2016 r. poz. 446).

18. K. Pawłowska, M. Swaryczewska, op. cit., s. 9-10.

19. J. Pruszyński, Dziedzictwo kultury Polski., T. 1, s. 47.

20. K. Zeidler, Prawo ochrony dziedzictwa kultury, Warszawa 2007, s. 103. składników tego dziedzictwa dostrzec można ich wpływ na jakość życia mieszkańców, wizerunek jednostki samorządu, rozwój społeczny i gospodarczy ${ }^{18}$. Nie ma gmin pozbawionych dziedzictwa kulturowego, choć niewątpliwie potencjał poszczególnych wspólnot bardzo się różni. Trzeba jednak pamiętać, że wszystko, co nas otacza, jest w jakimś sensie dziedzictwem, jako świadectwo naszej cywilizacji i kultury. Jednocześnie prawo do konkretnego dziedzictwa mają ci, którzy poczuwają się do związków z nim, rozumieją potrzebę jego kultywowania i opieki ${ }^{19}$.

Dziedzictwo kulturowe stało się na przestrzeni stuleci wartością integrującą i taką rolę pełni ono nadal. Dla odbudowywanego po 1990 r. samorządu terytorialnego tworzy fundament budowania tożsamości lokalnej i źródło identyfikacji z lokalną społecznością. Dlatego troska o stan dziedzictwa kulturowego powinna przejawiać się w działaniach władz lokalnych i w aktywności samych mieszkańców. Jednak szukając w katalogu zadań samorządu gminnego tych związanych z ochroną dziedzictwa kulturowego, należy zauważyć, że w ustawie o samorządzie gminnym kwestia ta uregulowana została tylko poprzez wskazanie w art. 7 ust. 1 pkt 9, że do zadań w zakresie kultury należą także zadania w obszarze ochrony zabytków i opieki nad zabytkami. Potwierdza to spostrzeżenie, że działania jednostek samorządu terytorialnego koncentrują się przede wszystkim na ochronie materialnego zasobu dziedzictwa kultury²0.

Więcej o obowiązkach gmin w obszarze ochrony dziedzictwa kulturowego stanowi ustawa

Miasto. Pamięć i Przyszłość 1 (2016) ISSN 2543-621X 
o ochronie zabytków i opiece nad zabytkami21 (u.o.z.). Zgodnie z art. 4 ochrona zabytków polega na podejmowaniu przez organy administracji publicznej (zatem i administracji samorządowej) działań mających na celu m.in.: zapewnienie warunków umożliwiających trwałe zachowanie zabytków, ich zagospodarowanie i utrzymanie, zapobieganie zagrożeniom mogącym spowodować uszczerbek na wartości zabytków, udaremnienie niszczenia i niewłaściwego korzystania, kontrolę stanu zachowania i przeznaczenia zabytków, uwzględnianie zadań ochronnych w planowaniu przestrzennym. Ponadto ustawa w art. 7 przewiduje cztery formy ochrony zabytków, którymi są: wpis do rejestru zabytków, uznanie za pomnik historii, utworzenie parku kulturowego, ustalenie ochrony w miejscowym planie zagospodarowania przestrzennego. Dla gmin szczególne znaczenie mają dwie ostatnie formy.

Kształtowanie i prowadzenie polityki przestrzennej, przede wszystkim w drodze uchwalania miejscowego planu zagospodarowania przestrzennego, stanowi zadanie własne gminy²2. Zarówno studium uwarunkowań i kierunków zagospodarowania przestrzennego jak i miejscowy plan zagospodarowania przestrzennego, muszą uwzględniać stan dziedzictwa kulturowego i ochronę zabytków²3. Ponadto od przyjęcia tzw. ustawy krajobrazowej w studium uwarunkowań powinny być brane pod uwagę rekomendacje i wnioski umieszczone w audycie krajobrazowym lub wskazania przez audyt granic krajobrazów priorytetowych, a w przypadku planów miejscowych - muszą one obowiązkowo określać zasady

\section{Miasto. Pamięć i Przyszłość 1 (2016) ISSN 2543-621X}

kształtowania krajobrazu oraz ochrony dziedzictwa kulturowego i zabytków, w tym krajobrazów kulturowych ${ }^{24}$. Zmiany te są realizacją zapisów wspomnianej już Europejskiej Konwencji Krajobrazowej, akcentującej kompleksowe podejście do krajobrazu (bez podziału na krajobraz przyrodniczy i kulturowy), i odpowiedzią na szczątkowe i rozproszone uregulowanie tych kwestii w polskim ustawodawstwie, skutkujące dwutorowym (osobno dziedzictwo przyrodnicze, osobno kulturowe) i fragmentarycznym systemem ochrony ${ }^{25}$.

Wspomniana „ustawa krajobrazowa” znowelizowała również przepisy odnoszące się do procedury tworzenia parku kulturowego. Po kilkunastu latach od uchwalenia ustawy o ochronie zabytków i opiece nad zabytkami trudno już mówić, że park kulturowy to nowa instytucja prawna ${ }^{26,}$ choć jest najmłodszą formą ochrony zabytków. Pierwsze regulacje wprowadzające tę instytucję przyjęto nowelizacją w 1990 r. ustawy o ochronie dóbr kultury z 1962 r., wskazując, że przedmiotem ochrony może być krajobraz

21. (Tekst jedn. Dz. U. z 2014 r. poz. 1446, z późn. zm.)

22. Ustawa z dnia 23 marca 2003 r. o planowaniu i zagospodarowaniu przestrzennym (tekst jedn. Dz. U. z 2016 r. poz. 778).

23. Art. 18 ust. 1 ustawy o ochronie zabytków i opiece nad zabytkami.

24. Zob. art. 7 pkt 2 ustawy z dnia 24 kwietnia 2015 o zmianie niektórych ustaw w związku ze wzmocnieniem narzędzi ochrony krajobrazu, Dz. U. poz. 774, z późn. zm.

25. Projekt ustawy o zmianie niektórych ustaw w związku ze wzmocnieniem narzędzi ochrony krajobrazu. Uzasadnienie, s. 5, Druk Sejmowy nr 1525, http://orka.sejm.gov.pl/Druki7ka.nsf/0/ E0EC31AF25E44523C1257BA4002A90F4/\%24File/1525.pdf (dostęp: 11.VIII.2016r.). Na aspekt ten zwrócono uwagę m.in. w pracy: Raport na temat systemu funkcjonowania systemu ochrony dziedzictwa kulturowego w Polsce po roku 1989, red. J. Purchla, Warszawa 2009, s. 46 nn.

26. Por. K. Zeidler, op. cit., s. 155, I. Lipińska, Turystyka dziedzictwa kulturowego - wybrane aspekty ochrony prawnej parku kulturowego, "Turystyka Kulturowa” nr 3/2011, s. 16, http://www.turystykakulturowa.org/pdf/2011_03_02.pdf (dostęp: 17 VIII 2016r.). 
kulturowy - w formie ustanawianych stref ochrony konserwatorskiej, rezerwatów i parków kulturowych ${ }^{27}$. Wydaje się jednak, że jako forma ochrony zabytków park kulturowy słabo zaistniał w świadomości zarówno władz lokalnych, jak i lokalnych społeczności. Do tej pory powstało 30 parków kulturowych - 29 utworzonych przez gminy i jeden stworzony przez związek gmin²8, co przy liczbie prawie 2500 gmin oznacza, że na zastosowanie takiej formy ochrony dziedzictwa zdecydowało nieco ponad 1\% z nich.

Warto zaznaczyć, że tworzenie parków kulturowych jest wyłączną kompetencją gmin pozwalającą na realizację zasady subsydiarności w ochronie dziedzictwa kulturowego ${ }^{29}$. Zgodnie z art. 16 ust. 1 u.o.z. w ramach parków ochronie podlegają krajobraz kulturowy oraz wyróżniające się krajobrazowo tereny z zabytkami nieruchomymi charakterystycznymi dla miejscowej tradycji budowlanej i osadniczej. Nowelizacja ustawy prócz zmian w procedurze tworzenia parku, które zostaną omówione w dalszej części opracowania, wprowadziła w art. 3 pkt 14 nową definicję krajobrazu kulturowego. Obecnie oznacza on „postrzeganą przez ludzi przestrzeń, zawierającą elementy przyrodnicze i wytwory

27. K. Zalasińska, Ochrona zabytków, Warszawa 2010, s. 115.

28. Lista parków kulturowych - stan na 31 grudnia 2015, http:// www.nid.pl/pl/Informacje_ogolne/Zabytki_w_Polsce/Parki_kulturowe/Zestawienie_parkow/miejsce.php?ID=30 (dostęp: 17 VIII 2016r.). Liczba ta nie jest jednak aktualna. Uchwałą nr XII/183/2015 z dnia 3 września 2015 r. Rada Miasta Zakopane zdecydowała o utworzeniu „Parku Kulturowego obszaru Krupówki", http://bip.zakopane.eu/zalacznik/17563 (dostęp: 17 VIII 2016r.).

29. K. Zeidler, op. cit., s 155.

30. Por. M. Rouba, op. cit., s. 111-115.

31. Program opieki nad zabytkami województwa dolnośląskiego na lata 2015-2018, s. 31, http://www.umwd.dolnyslask.pl/fileadmin/ user_upload/Biuro_Prasowe/Grudzien_2014/Program_Zabytki. pdf, (dostęp: 17 VIII 2016r.). cywilizacji, historycznie ukształtowaną w wyniku czynników naturalnych i działania człowieka". Utworzenie parku kulturowego nakłada na jednostkę samorządu pewne obowiązki, w tym sporządzenie planu ochrony parku kulturowego czy miejscowego planu zagospodarowania przestrzennego dla obszarów parku (art. 16 ust. 3 i 6).

Uchwalanie miejscowego planu zagospodarowania przestrzennego i tworzenie parków kulturowych to najczęściej wskazywane, ale nie jedyne kompetencje samorządu gminnego w ochronie dziedzictwa kulturowego. Ważnym narzędziem zarządzania lokalnym dziedzictwem mogą być programy ochrony zabytków i opieki nad zabytkami, których kwestię reguluje art. 87 ust. 1 i 2 u.o.z. Sporządzane na okres czterech lat na wszystkich szczeblach samorządu mają na celu: włączenie problemów ochrony zabytków do systemu zadań strategicznych, łączenie uwarunkowań ochrony zabytków i krajobrazu z uwarunkowaniami ochrony przyrody, zahamowanie procesu degradacji zabytków i poprawę stanu ich zachowania, wyeksponowanie poszczególnych zabytków i walorów krajobrazowych, zwiększanie atrakcyjności zabytków dla potrzeb społecznych, turystycznych i edukacyjnych, określenie warunków współpracy z właścicielami zabytków czy wspieranie inicjatyw służących zwiększaniu środków finansowych na opiekę nad zabytkami30. Niestety, programy opieki nad zabytkami, choć mogłyby stanowić podstawę kreowania spójnej polityki w zakresie ochrony zabytków, posiadało w 2014 r. około 15\% dolnośląskich gmin i 10\% powiatów ${ }^{31}$. Nie oznacza to jednak,

Miasto. Pamięć i Przyszłość 1 (2016) ISSN 2543-621X 
że samorządy nie podejmują działań w tej sferze, gdyż wiele z nich mimo braku programów przeznacza środki na dotacje celowe na prace konserwatorskie, a w dokumentach strategicznych jednostek samorządu wykorzystanie dziedzictwa kulturowego stanowi ważny aspekt rozwoju.

Warto w tym miejscu wspomnieć o jeszcze jednej formie decentralizacji w sferze ochrony zabytków wskazanej w art. 96 ust. 2 u.o.z., jaką jest powierzanie, w drodze porozumienia, niektórych uprawnień z zakresu właściwości wojewody (w tym wydawania decyzji administracyjnych), gminom i powiatom. Przez 10 lat funkcjonowania ustawy zawarto 65 takich porozumień, na mocy których działają samorządowi (miejscy lub powiatowi) konserwatorzy zabytków. Zarówno zakres kompetencji, jak i sposób formalnego umocowania konserwatorów bardzo się różnią. Widoczna jest dowolność w sposobie powoływania, ale także w obszarze stawianych im wymagań. Jedynie województwo pomorskie zdecydowało się na ujednolicenie zakresu kompetencji przekazywanych samorządowym konserwatorom zabytków ${ }^{32}$. W województwie dolnośląskim zawarto trzy porozumienia, na mocy których kompetencje wojewody przekazane zostały jednej gminie i dwóm powiatom, a realizują je odpowiednio: Miejski Konserwator Zabytków we Wrocławiu, prezydent Legnicy i burmistrz Bielawy. Samorządowi konserwatorzy zabytków stanowić mogą znaczące odciążenie w realizacji zadań państwowej służby ochrony zabytków. W istotny sposób wpływają bowiem na działania organów

Miasto. Pamięć i Przyszłość 1 (2016) ISSN 2543-621X 91 pierwszej instancji w postępowaniu administracyjnym, ponieważ 20-25\% wszystkich aktów administracyjnych jest wynikiem ich bieżącej działalności33. Choćby z tego względu postulat powołania samorządowych służb ochrony zabytków ma wielu zwolenników ${ }^{34}$.

\section{Park kulturowy jako forma ochrony}

Jak wspomniano wcześniej, w Polsce istnieje ponad 30 parków kulturowych zlokalizowanych na terenie 12 województw (nie ma parków kulturowych w województwach lubelskim, opolskim, podlaskim i zachodniopomorskim). Jednocześnie stanowią one bardzo niejednorodną formę ochrony krajobrazu kulturowego. Niektóre obejmują pojedyncze obiekty, a inne - jak „Park Kulturowy Kotliny Jeleniogórskiej” - rozciągają się na terenach należących do kilku gmin. Duża swoboda w zakresie ustalania obszaru oraz form oddziaływania na lokalne dziedzictwo kulturowe może stanowić zarówno przeszkodę, jak i ułatwienie. Zbyt sztywne ramy mogłyby zniechęcać gminy do tworzenia parków kulturowych, ale z drugiej strony nadmierna elastyczność pozostawiająca wiele niedopowiedzeń, np. w kwestii mocy prawnej planu ochrony parku kulturowego, który nie jest aktem prawa miejscowego, też im nie sprzyja ${ }^{35}$.

32. Krajowy program ochrony zabytków i opieki nad zabytkami na lata 2014-2017, s. 14-15, http://bip.mkidn.gov.pl/media/download_gallery/20140818Krajowy_Program_Ochrony_Zabytkow_i_ Opieki_nad_Zaby.pdf, (dostęp: 22 VIII 2016r.).

33. Ibidem, s. 15.

34. Por. J. Pruszyński, Dziedzictwo kultury Polski. Jego straty i ochrona prawna, T. 2, Zakamycze 2001, s . 464-466, K. Pawłowska, M. Swaryczewska, op. cit., s. 124-128, K. Zeidler, O właściwy kształt służby ochrony zabytków, [w:] Prawna ochrona dóbr kultury, op. cit., s. $38-45$.

35. Z. Myczkowski, Park kulturowy jako forma obszarowej ochrony zabytków, s. 108, http://www.nid.pl/upload/iblock/ce7/ce7b05a19dffda970503e48200c4da42.pdf, (dostęp: 24 VII 2016r.) 
Park kulturowy stanowi formę ochrony szczególnego rodzaju dziedzictwa, jakim jest krajobraz kulturowy. Zawarcie w u.o.z. przepisów regulujących ochronę krajobrazu odzwierciedla obserwowaną w XX w. zmianę podejścia do przedmiotu ochrony - już nie tylko pojedyncze zabytki czy ich zespoły traktowane są jako dobra publiczne o szczególnym znaczeniu, ale również przestrzeń o wyjątkowych walorach krajobrazowych może stać się obiektem chronionym ${ }^{36}$. Wskazuje się, że zachowanie i kształtowanie krajobrazu zależy w o wiele większym stopniu od poziomu świadomości historycznej i kulturalnej niż od przepisów prawa, co wynika m.in. z niedoprecyzowania pojęcia krajobrazu oraz trudności w tworzeniu narzędzi jego ochrony ${ }^{37}$. Ponadto choć katalog form ochrony krajobrazu jest stosunkowo szeroki, nie podąża za nim skuteczność, co w dużym stopniu wynika z konfliktu między wartościami przyrodniczymi i kulturowymi krajobrazu a społecznymi i ekonomicznymi racjami lokalizacji nowych inwestycji38.

Inicjatywa powołania parku kulturowego jest wyborem społeczeństwa39. Zainicjować ten proces mogą mieszkańcy, władze lokalne, organizacje społeczne, eksperci. Decyzja o jego utworzeniu wzbogaca istniejące w gminie formy ochrony

36. Zob. A. Przyborowska-Klimczak, op. cit., s. 23-26.

37. J. Pruszyński, Dziedzictwo kultury Polski, T. 2, s. 86.

38. Projekt ustawy o zmianie niektórych ustaw..., s. 6.

39. Zasady tworzenia Parku Kulturowego, zarzadzania nim oraz sporządzania planu jego ochrony, s. 4 http://www.nid.pl/pl//nformacje_ogolne/Zabytki_w_Polsce/Parki_kulturowe/Zasady\%20 tworzenia\%20Parku\%20Kulturowego,\%20zarz\%C4\%85dzania\%20 nim\%20oraz\%20sporz\%C4\%85dzania\%20planu\%20jego\%20 ochrony.pdf (dostęp: 24 VII 2016 r.).

40. K. Pawłowska, M. Swaryczewska, op. cit., s. 100.

41. Por. Leksykon prawa ochrony zabytków, s. 249, I. Lipińska, op. cit., s. 16.

42. Zasady tworzenia Parku Kulturowego..., s. 7. zabytków i musi być uzasadniona. Utrudnieniem mogą okazać się nie zawsze zgodne interesy i oczekiwania poszczególnych podmiotów. Niemniej jednak mieszkańcy czujący związek z miejscem, w którym żyją, i mający możliwość współdecydowania o jego losach będą lepszymi partnerami we wszelkich przedsięwzięciach prokrajobrazowych ${ }^{40}$. Zgodnie z art. 6 ust. 1 u.o.z. opiece i ochronie podlegają zabytki nieruchome będące w szczególności: krajobrazami kulturowymi, układami urbanistycznymi i ruralistycznymi (wiejskimi), zespołami budowlanymi, dziełami architektury i budownictwa, obiektami techniki, cmentarzami, parkami, ogrodami czy miejscami upamiętniającymi wydarzenia historyczne czy wybitne postaci. Ochrona krajobrazów przybierać może formę parku kulturowego, który pozwala zachować wyróżniające się krajobrazowo tereny z zabytkami nieruchomymi charakterystycznymi dla miejscowej tradycji budowlanej i osadniczej. Park kulturowy przedstawia wartość, jako całość i nie jest wymagane, by na jego terenie znajdowały się obiekty zabytkowe ${ }^{41}$. Jednak w praktyce na terenie wszystkich parków kulturowych istniejących w Polsce znajdują się obiekty wpisane do rejestru zabytków.

Decyzję o utworzeniu parku poprzedzić powinna identyfikacja reprezentatywnych i charakterystycznych cech krajobrazu kulturowego wyróżniających się na tle lokalnym, regionalnym czy ponadregionalnym². Jak wskazał w 2007 r. Naczelny Sąd Administracyjny, teren, który ma obejmować park, musi stanowić przestrzeń historycznie ukształtowaną działalnością człowieka,

Miasto. Pamięć i Przyszłość 1 (2016) ISSN 2543-621X 
zawierającą elementy przyrodnicze i wytwory cywilizacji, wyróżniać się krajobrazowo, może zawierać zabytki nieruchome charakterystyczne dla miejscowej tradycji, ale - co najistotniejsze - zachowanie jego walorów możliwe jest do osiągnięcia wyłącznie na drodze utworzenia parku, to znaczy że postanowienia miejscowego planu zagospodarowania przestrzennego i wpisanie poszczególnych obiektów do rejestru zabytków nie wystarczają do realizacji celu ochrony³.

Park kulturowy tworzony jest przez radę gminy w drodze uchwały, po zasięgnięciu opinii wojewódzkiego konserwatora zabytków (art. 16 ust. 1). Pewne zmiany w procedurze tworzenia parków wprowadziła tzw. ustawa krajobrazowa. Zmiany te uwzględniają uczestnictwo lokalnej społeczności (mieszkańców, przedsiębiorców, organizacji społecznych) w pracach nad ich powstawaniem. Artykuł 16 ust. 1a u.o.z. stanowi, że rada gminy ogłasza w lokalnej prasie i w sposób zwyczajowo przyjęty w danej miejscowości o podjęciu prac nad utworzeniem parku kulturowego, określając termin (nie krótszy niż 21 dni) i formę składania wniosków dotyczących projektu uchwały.

Uchwała o utworzeniu parku kulturowego określa nazwę parku, ustala jego granice, sposoby ochrony oraz szczególne zakazy i ograniczenia wprowadzane na terenie parku. Zgodnie z art. 17 ust. 1 u.o.z. na terenie parku lub jego części ustanowione mogą być zakazy i ograniczenia dotyczące: prowadzenia robót budowlanych, działalności przemysłowej, rolnej, handlowej czy usługowej, zmiany sposobu korzystania z zabytków nieruchomych, umieszczania tablic,

Miasto. Pamięć i Przyszłość 1 (2016) ISSN 2543-621X 93 napisów, ogłoszeń reklamowych, zasad i warunków sytuowania obiektów małej architektury, składowania lub magazynowania odpadów. Gmina może zatem w sposób bardzo elastyczny kształtować instrumenty ochrony w ramach parku kulturowego, ograniczając się do wąskiego katalogu zakazów (np. zakaz lokalizowania nowych miejsc składowania odpadów w Parku Kulturowym Kotliny Jeleniogórskiej) lub regulując ją kompleksowo, jak w przypadku Parku Kulturowego Stare Miasto w Krakowie, gdzie wprowadzono szereg ograniczeń w sferze prowadzenia robót budowlanych, działalności usługowej, a także zakazy i ograniczenia dotyczące umieszczania nośników reklamowych i informacji wizualnej oraz instalowania urządzeń na elewacjach frontowych budynków ${ }^{44}$.

Wejście w życie uchwały o utworzeniu parku kulturowego dopiero rozpoczyna ochronę krajobrazu kulturowego w gminie, gdyż warunkiem niezbędnym pełnego wdrożenia tego procesu jest sporządzenie planu ochrony parku kulturowego oraz miejscowego planu zagospodarowania przestrzennego dla obszarów położonych na terenie parku (art. 16 ust. 3 i 6 u.o.z.). Plan ochrony parku jest przygotowywany przez wójta, burmistrza lub prezydenta miasta w uzgodnieniu z wojewódzkim konserwatorem zabytków. Najczęściej gminy przystępują do prac nad planem w kolejnym etapie. Ustawa o ochronie zabytków nie określa terminu rozpoczęcia prac nad opracowaniem wskazanych dokumentów, jednak zgodnie z ustawą o planowaniu

43. Wyrok NSA z 4 kwietnia 2007 r., II OSK 7/07.

44. Uchwała nr CXV/1547/10 Rady Miasta Krakowa z dnia 3 listopada 2010 r. w sprawie utworzenia parku kulturowego pod nazwą Park Kulturowy Stare Miasto, (Dz. Urz. Woj. Małopolskiego z 2010 r. Nr 647, poz. 5336). 
i zagospodarowaniu przestrzennym dla miejscowego planu zagospodarowania przestrzennego są to trzy miesiące od daty utworzenia parku ${ }^{45}$.

Plan ochrony parku jest dokumentem wewnętrznym gminy służącym praktycznej realizacji celów parku kulturowego i określającym ramy programu zarządzania parkiem. Powinien być zwięzły, czytelny, zrozumiały - także dla społeczności lokalnej, grup interesu, właścicieli zabytków ${ }^{46}$. Sporządzenie planu wymaga często silnego wsparcia eksperckiego i nakładów finansowych. Problemy organizacyjno-finansowe spowodowały, że Park Kulturowy Kotliny Jeleniogórskiej w siedem lat po utworzeniu nadal nie posiada tego dokumentu niezbędnego do rzeczywistego objęcia ochroną terenów parku kulturowego. Plany ochrony istotnie się różnią. Znaleźć można dokumenty kilkunastostronicowe i kompleksowe opracowania, jak Plan ochrony Parku Kulturowego Stare Miasto w Krakowie liczący ponad dwieście stron ${ }^{47}$. Powstaje też pytanie o aktualność niektórych planów, przygotowanych wiele lat temu, jak plan ochrony pierwszego utworzonego w 2002 r. w Polsce parku kulturowego, czyli Fortecznego Parku Kulturowego Srebrna Góra z 2004 r. ${ }^{48}$. Zapewne część celów wskazanych w planie została zrealizowana, być może pojawiły się nowe wyzwania wynikające

45. Zasady tworzenia Parku Kulturowego..., s. 10.

46. Ibidem, s. 3.

47. Plan ochrony Parku Kulturowego Stare Miasto w Krakowie, przyjęty uchwałą nr XLII/544/12 Rady Miasta Krakowa z dnia 4 kwietnia 2012 r. https://www.bip.krakow.pl/_inc/rada/uchwaly/ show_pdf.php?id=62701, (dostęp: 18 VIII 2016 r.).

48. Plan ochrony Fortecznego Parku Kulturowego w Srebrnej Górze, http://stoszowice.pl/download/File/pliki_pdf/Plan_Ochrony_Parku. pdf (dostęp: 26 VIII 2016 r.).

49. I. Lipińska, op. cit., s. 19.

50. A. Michalak, A. Ginter, Ustawa o ochronie zabytków i opiece nad zabytkami. Komentarz, Warszawa 2016, s. 130-131. z przekształceń uwarunkowań prawnych, społecznych czy ekonomicznych. Wydaje się, że plan ochrony parku kulturowego nie jest dokumentem danym raz na zawsze i powinien podlegać aktualizacji w jakiejś perspektywie czasowej, jak ma to miejsce np. w przypadku samorządowych programów ochrony zabytków i opieki nad zabytkami, lub przynajmniej okresowej ocenie.

W celu realizacji zadań związanych z ochroną parku rada gminy może utworzyć jednostkę organizacyjną do zarządzania parkiem. Powołane jednostki nie mają jednoznacznie sprecyzowanej formy organizacyjno-prawnej - funkcjonują one zarówno jako wydzielone komórki w ramach urzędów gmin, jak i spółki prawa handlowego. Aktywny udział w zarządzaniu parkiem biorą także organizacje społeczne ${ }^{49}$.

Wskazywanym w literaturze problemem jest konkurencyjność ochrony w ramach parku kulturowego względem wprowadzanych równolegle form ochrony przyrody. Bardzo często obszary o szczególnych walorach krajobrazowych łączą w sobie wartości przyrodnicze i kulturowe. Brak spójności między przepisami regulującymi ochronę zabytków i ochronę przyrody staje się źródłem konfliktów. Stąd wniosek, że pożądana metoda wartościowania i oceny krajobrazu kulturowego wykracza poza założenia przyjęte w u.o.z., ponieważ nie powinno się oddzielać wartości kulturowych od przyrodniczych ${ }^{50}$.

Nie wszystkie inicjatywy utworzenia parków kulturowych okazały się skuteczne. Uchwały o utworzeniu parku są przedmiotem skarg kierowanych do wojewódzkich sądów

Miasto. Pamięć i Przyszłość 1 (2016) ISSN 2543-621X 
administracyjnych czy skarg kasacyjnych do Naczelnego Sądu Administracyjnego. Przywoływany już wyrok NSA uchylił zaskarżony wyrok WSA w Kielcach stwierdzającego wydanie z naruszeniem prawa uchwały w sprawie utworzenia Parku Kulturowego Miasta Końskie i oddalił skargę na uchwałę gminy. Skuteczna okazała się natomiast skarga na uchwałę Rady Miasta Krakowa o utworzeniu Zwierzynieckiego Parku Kulturowego, obejmującego jedną z dzielnic Krakowa, w przypadku której wojewódzki sąd administracyjny stwierdził nieważność zaskarżonej uchwały ${ }^{51}$. Potwierdza to tezę, że podejmowanie działań w zakresie ochrony dziedzictwa bez współudziału mieszkańców nie sprzyja ich skuteczności, a niekiedy prowadzi do poważnych konfliktów, a doświadczenia pokazują, że same zapisy porządkujące nie zmieniają stanu rzeczy, ponieważ potrzebna jest przede wszystkim przemyślana strategia informacyjna i edukacja52. Prawo do współdecydowania o losach miejsca, w którym się żyje, jest jednym z podstawowych praw człowieka, a decyzje dotyczące ochrony bezpośrednio wpływają na życie mieszkańców ${ }^{53}$.

Konstatacja zawarta kilka lat temu w Raporcie na temat systemu funkcjonowania systemu ochrony dziedzictwa kulturowego w Polsce po roku $1989^{54}$ wydaje się nadal aktualna. Narzędzie zarządzania krajobrazem w postaci parku kulturowego nie funkcjonuje zgodnie z oczekiwaniami, nawet jeśli rekomendacje administracji szczebla regionalnego wskazują zasadność tworzenia parków kulturowych na terenie danego województwa ${ }^{55}$.

Miasto. Pamięć i Przyszłość 1 (2016) ISSN 2543-621X 95

\section{Parki kulturowe na Dolnym Śląsku}

Program Ochrony Zabytków Województwa Dolnośląskiego na lata 2007-2011 zakładał działania mające na celu opracowanie koncepcji sieci parków kulturowych oraz studiów określających ich granice. Jak wskazali w 2014 r. autorzy kolejnego programu, przygotowanego na lata 2015-2018 założenie to nie zostało zrealizowane ${ }^{56}$. Nie oznacza to, że parki kulturowe na terenie województwa nie powstają. Dzieje się to jednak bez systemowego wsparcia samorządu województwa. Na terenie Dolnego Śląska funkcjonują cztery parki kulturowe: Forteczny Park Kulturowy w Srebrnej Górze (utworzony w 2002 r.), Forteczny Park Kulturowy Twierdza Kłodzka (2003 r.), Park Kulturowy Kotliny Jeleniogórskiej (2009 r.) oraz Park Kulturowy Stare Miasto we Wrocławiu (2014 r. $)^{57}$. Szerzej przedstawione zostaną dwa ostatnie.

Park Kulturowy Kotliny Jeleniogórskiej powstał na mocy uchwały Zgromadzenia Związku Gmin Karkonoskich z 2009 r.58. Akt ten poprzedzony

51. Uchwała nr CXIV/1174/06 Rady Miasta Krakowa z dnia 6 lipca 2006 r. w sprawie utworzenia parku kulturowego pod nazwą "Zwierzyniecki Park Kulturowy" (Dz. Urz. Woj. Małopolskiego z 2006 r. Nr 427, poz. 2710), Wyrok WSA w Krakowie z dnia 3 kwietnia 2007 r., III SA/Kr 55/07.

52. Jak wykorzystać potencjat "ustawy krajobrazowej”. Instrumenty prawne i propozycje. Przewodnik dla samorzadu gminnego, Gdańsk 2016, s. 9, http://www.im.edu.pl/wp-content/ uploads/2011/06/20160302_podrecznik.pdf (dostęp: 10 VIII 2016 r.).

53. K. Pawłowska, M. Swaryczewska, op. cit., s. 65.

54. Raport na temat funkcjonowania systemu ochrony dziedzictwa kulturowego w Polsce po roku 1989, red. J. Purchla, Warszawa 2009. 55. Ibidem, s. 49.

56. Program opieki nad zabytkami województwa dolnośląskiego na lata 2015-2018, s. 31.

57. Lista parków kulturowych - stan na 31 grudnia 2015.

58. Uchwała Zgromadzenia Związku Gmin Karkonoskich nr 48/ XVII/09 z dnia 30 stycznia 2009 r. w sprawie utworzenia parku kulturowego pod nazwą „Park Kulturowy Kotliny Jeleniogórskiej” (Dz. Urz. Woj. Dolnośląskiego z 2009 r. Nr 42, poz. 890 z późn. zm.). 
został zgodnymi uchwałami rad gmin Mysłakowice i Podgórzyn i Rady Miasta Kowary, pozytywnie opiniujących utworzenie parku. Jako cel powołania parku wskazano: ochronę zabytków, walorów kulturowych i krajobrazowych oraz zintegrowane zarządzanie ochroną i udostępnianiem parku. Jedyny wprowadzony uchwałą zakaz dotyczył lokalizowania nowych miejsc składowania i magazynowania odpadów poza przeznaczonymi do tego pojemnikami. Jednocześnie przyjęto, że powołany zostanie Zarząd Parku jako jednostka organizacyjna Związku Gmin Karkonoskich. Park ten ponadto jest jedynym w Polsce utworzonym decyzją więcej niż jednej gminy. Niestety, historia funkcjonowania parku wskazuje, że być może będzie on pierwszym parkiem kulturowym, który zostanie zlikwidowany.

Idea stworzenia Parku Kulturowego Kotliny Jeleniogórskiej nie budziła kontrowersji. Wartości krajobrazowe i kulturowe Kotliny Jeleniogórskiej decydują o turystycznej atrakcyjności położonych w jej obrębie gmin i stanowią podstawę rozwoju tych terenów. Połączenie szczególnych walorów przyrodniczych z bogactwem dziedzictwa kulturowego w postaci unikalnego kompleksu kilkudziesięciu założeń parkowo-pałacowych traktować należy jako wyjątkowy zasób, wymagający wzmożonej ochrony ${ }^{59}$. Konsekwencją utworzenia parku miała być szeroko rozumiana promocja regionu w oparciu o walory krajobrazowe

59. K. Korzeń, Park Kulturowy Kotliny Jeleniogórskiej, „Urbanista” nr 11/2008, s. 22, http://www.dolinapalacow.pl/zdjecia/2008_ 11-Park_Kulturowy_Kotliny_Jeleniogorskiej\%20-Urbanista.pdf (dostęp: 25 VII 2008r.).

60. K. Korzeń, Park Kulturowy Kotliny Jeleniogórskiej. „Dolina Pałaców i Ogrodów", s. 4, http://www.karkonosze.eu/files/park-kulturowy/09-KK-Konc.PKKJ.pdf (dostęp: 24 VII 2016 r.).

61. Rozporządzenie Prezydenta RP z dnia 20 września 2011 r. w sprawie uznania za pomnik historii „Pałace i parki krajobrazowe Kotliny Jeleniogórskiej”, Dz. U. nr 217, poz.1283. i kulturowe słabo jeszcze rozpoznawalne, zarówno w skali regionalnej, jak i krajowej.

Rozwinięcie ogólnie wskazanych w uchwale celów utworzenia parku wskazywało na: wzmocnienie skuteczności ochrony krajobrazu kulturowego łączącej ochronę obiektów i zespołów zabytkowych z ochroną przyrody i stwarzającej warunki zrównoważonego rozwoju przestrzennego i społeczno-gospodarczego wschodniej części Kotliny Jeleniogórskiej; zachowanie i utrzymywanie cech krajobrazu tych terenów, a przede wszystkim położonych na nich rezydencji wraz z ich powiązaniami kompozycyjnymi i widokowymi oraz zharmonizowanie z nimi dalszych zmian zagospodarowania przestrzennego obszaru ${ }^{60}$. W obrębie parku zajmującego prawie trzy tysiące hektarów znalazło się trzynaście zespołów parkowo-pałacowych i trzydzieści innych obiektów wpisanych do rejestru zabytków. Co ciekawe, obiekty te nie zajmują zwartego obszaru, ponieważ część parku położona w gminie Podgórzyn nie sąsiaduje z terenami parku położonymi w gminach Kowary i Mysłakowice.

Znaczenie dziedzictwa kulturowego, które znalazło się na obszarze Parku Kulturowego Kotliny Jeleniogórskiej potwierdzone zostało w 2011 r., kiedy na mocy rozporządzenia Prezydenta RP parki i pałace Kotliny Jeleniogórskiej (łącznie jedenaście zespołów parkowo-pałacowych) uznane zostały za pomnik historii61. Ponadto w 2015 r. Fundacja Doliny Pałaców i Ogrodów Kotliny Jeleniogórskiej przygotowała wniosek o rozpatrzenie kandydatury utworzonego pomnika historii do oficjalnej listy

Miasto. Pamięć i Przyszłość 1 (2016) ISSN 2543-621X 
zawierającej dobra, które mogą być nominowane do wpisu na Listę Światowego Dziedzictwa UNESCO ${ }^{62}$.

Kolejnym krokiem następującym po uchwale tworzącej park kulturowy powinno być przygotowanie planu ochrony parku i miejscowych planów zagospodarowania przestrzennego dla obszarów objętych parkiem. W 2014 r. Zarząd Związku Gmin Karkonoskich podjął uchwałę w sprawie ustalenia procedury likwidacji parku, uzasadniając to niespełnieniem przez Związek i gminy, które utworzyły park, wymogów przewidzianych w uchwale o jego utworzeniu, czyli brakiem planu ochrony i miejscowych planów zagospodarowania oraz zaniechaniem powołania jednostki organizacyjnej do zarządu parkiem. W zaistniałej sytuacji należy rozważyć możliwość likwidacji Parku Kulturowego Kotliny Jeleniogórskiej i wystąpienie do gmin, które utworzyły park, oraz wojewódzkiego konserwatora zabytków o opinię w tej sprawie. Po uzyskaniu opinii Zarząd Związku Gmin Karkonoskich przygotuje uchwałę w sprawie likwidacji parku kulturowego ${ }^{63}$. Jeszcze w tym samym roku Rada Gminy Mysłakowice podjęła uchwałę o uchyleniu uchwały z 2008 r. w sprawie zaopiniowania projektu utworzenia Parku Kulturowego Kotliny Jeleniogórskiej64. Obie uchwały nie zostały ogłoszone w Dzienniku Urzędowym Województwa Dolnośląskiego.

Trudno jednoznacznie wskazać przyczyny niepowodzenia idei Parku Kulturowego Kotliny Jeleniogórskiej. Już sam fakt utworzenia parku decyzją trzech gmin, których interesy nie zawsze muszą być zgodne, stanowi utrudnienie w wypracowaniu

Miasto. Pamięć i Przyszłość 1 (2016) ISSN 2543-621X 97 wspólnego stanowiska. Ponadto, znaczny obszar parku, wielość obiektów zabytkowych położonych na jego obszarze nie sprzyjają identyfikowaniu się społeczności lokalnych z pomysłem szczególnej ochrony tego krajobrazu kulturowego, który postrzegany bywa przez pryzmat najbliższego otoczenia. Pomysły ochrony zabytków Kotliny Jeleniogórskiej miały swoje istotne źródło w kręgach eksperckich i podmiotach społecznych, którym chyba nie udało się przekonać do intensywniejszych działań ani mieszkańców poszczególnych gmin, ani władz samorządowych. Dziś bardziej rozpoznawalna jest Dolina Pałaców i Ogrodów Kotliny Jeleniogórskiej, promowana przez fundację o tej samej nazwie, niż Park Kulturowy Kotliny Jeleniogórskiej, którego o istnieniu nie wiedzą nawet mieszkańcy gmin opiniujących jego utworzenie.

Park Kulturowy Kotliny Jeleniogórskiej nie jest jedynym, którego funkcjonowanie uznać należy za zagrożone. We wrześniu 2015 r. władze Zakopanego przyjęły uchwałę o utworzeniu parku kulturowego pod nazwą „Park Kulturowy obszaru ulicy Krupówki" ${ }^{\prime \prime 5}$. Jednocześnie pojawiły się głosy

62. 1502-Wn.-o-rozp.-kand.DPiO-KJ-na-liste-UNESCO.doc (dostęp: 24 VII 2016r.).

63. Uchwała nr 15/59/14 Zarządu Związku Gmin Karkonoskich z dnia 25 września 2014 r. w sprawie ustalenia procedury koniecznej do likwidacji Parku Kulturowego pod nazwą Park Kulturowy Kotliny Jeleniogórskiej, http://www.zgk-karkonosze.pl/bip/pliki/ uchawly/2014/Zarzad_115_59_14.pdf (dostęp: 24 VII 2016 r.).

64. Uchwała nr LVI/349/14 Rady Gminy Mysłakowice z dnia 12 listopada 2014 r. w sprawie uchylenia uchwały nr 111/XVIII/2008 Rady Gminy Mysłakowice z dnia 28 marca 2008 r. w sprawie zaopiniowania projektu utworzenia parku kulturowego pod nazwą Park Kulturowy Kotliny Jeleniogórskiej, http://myslakowice.bip.net. pl/?p=document\&action=save\&id=3644\&bar_id=4437 (dostęp: 24 VII 2016 r.).

65. Uchwała nr XII/183/2015 Rady Miasta Zakopane z dnia 3 września 2015 r. w sprawie utworzenia parku kulturowego pod nazwą „Park Kulturowy obszaru ulicy Krupówki”, nie została opublikowana w Dzienniku Urzędowym Województwa Małopolskiego. http:// bip.zakopane.eu/zalacznik/17563, (dostęp: 17 VIII 2016 r.). 
za likwidacją istniejącego od wielu lat Parku Kulturowego Kotliny Zakopiańskiej, obejmującego swoim zasięgiem okolice Zakopanego, a powołanego przed uchwaleniem miejscowego planu zagospodarowania przestrzennego dla tych terenów. Wniosek o uchylenie uchwały z 2007 r. tworzącej park złożył jeden z miejskich radnych, argumentując go ograniczaniem przez tę formę ochrony dziedzictwa rozwoju obrzeży miasta66.

\section{Park Kulturowy "Stare Miasto” we Wrocławiu}

Jakość przestrzeni miejskiej, w tym miast zabytkowych, stanowi przedmiot refleksji urbanistów, architektów, historyków sztuki, samorządowców czy inwestorów. Zagadnienie to interesuje także mieszkańców, lokalną prasę i specjalistów ${ }^{67}$. Dlatego ochrona miejskich przestrzeni zabytkowych stała się przedmiotem szerszych opracowań, akcentujących konieczność nowego podejścia do zarządzania miastami historycznymi i powstania koncepcji „miasta dziedzictwa”. "Miasto dziedzictwa” nie jest sumą zachowanych zabytków, ale współcześnie kreowanym zjawiskiem, które każde pokolenie tworzy od nowa, w zgodzie z przeważającymi postawami wobec przeszłości, jest nową filozofią planowania dziedzictwa jako strategii zarządzania zmianami w jego obszarze ${ }^{68}$.

66. http://podhale24.pl/aktualnosci/artykul/42637/Park_Kulturowy_Kotliny_Zakopianskiej_do_likwidacji.html (dostęp: 23 VII 2016 r.) 67. M. Rouba, op. cit., s. 123

68. Zob. G. Ashworth, Planowanie dziedzictwa, Kraków 2015, s. $147-155$.

69. Rekomendacja UNESCO w sprawie historycznego krajobrazu miejskiego z dnia 10 listopada 2011 r. http://www.unesco.pl/ fileadmin/user_upload/pdf/Rekomendacje/rekomenkrajobraz.pdf (dostęp: 24 VII 2016 r.)

70. Uzasadnienie, s. 1, http://www.wroclaw.pl/files/urzad/konsultacje\%20spoleczne/uzasadnienie.pdf (odczyt: 10 VIII 2016 r.).
W preambule rekomendacji UNESCO ${ }^{69}$ w sprawie historycznego krajobrazu miejskiego wskazano, że historyczne obszary miejskie należą do najbogatszych i najbardziej zróżnicowanych przejawów dziedzictwa kulturowego, a dziedzictwo miejskie stanowi kapitał społeczny, kulturowy i ekonomiczny pozwalający na poprawę warunków życia ludności, sprzyjający rozwojowi ekonomicznemu i spójności społecznej. Jednocześnie szybki, często niekontrolowany rozwój obszarów miejskich może powodować fragmentaryzację oraz degradację dziedzictwa. Dlatego ochrona dziedzictwa miejskiego powinna stać się elementem ogólnej polityki w zakresie planowania i sposobów działania, poszukującej równowagi między ochroną a zrównoważonym rozwojem.

Wspomniane rekomendacje stały się jedną z inspiracji działań podjętych przez władze Wrocławia mających na celu ochronę krajobrazu kulturowego najstarszych części miasta. Projekt uchwały o utworzeniu parku kulturowego przygotowano w 2013 r. W uzasadnieniu projektu wskazano na szczególne walory dziedzictwa materialnego wrocławskiego Starego Miasta i Wysp Odrzańskich, ale zaakcentowano także elementy niematerialne (wyrazisty charakter, unikalną atmosferę i lokalne zwyczaje), które stanowią o jego wyjątkowości70. Wyraźnie sformułowanym motywem utworzenia parku była „troska o wizerunek miasta i potrzeba uporządkowania, zachowania i właściwego kształtowania krajobrazu kulturowego i historycznego charakteru przestrzeni publicznej [...], tak aby służył on w równej mierze właścicielom, użytkownikom,

Miasto. Pamięć i Przyszłość 1 (2016) ISSN 2543-621X 
mieszkańcom, przedsiębiorcom, władzom lokalnym i gościom - w najszerszym znaczeniu"71.

Przyjęcie uchwały poprzedzono szerokimi konsultacjami społecznymi, które zakończyły się w styczniu 2014 r. Złożono dwadzieścia propozycji poprawek, ale żadna z nich nie kwestionowała samej idei parku. Jednak podobnie jak w przypadku innych parków kulturowych w Polsce, także w tym wypadku pojawiły się podmioty kwestionujące część przyjętych regulacji. Skargi na uchwałę o utworzeniu parku kulturowego ${ }^{72}$ złożyli: wojewoda dolnośląski Tomasz Smolarz w trybie przepisów o nadzorze oraz spółka prawa handlowego International Fun Center w trybie art. 101 ustawy o samorządzie gminnym. W obu przypadkach Rada Miejska Wrocławia wnosiła o oddalenie skargi do Wojewódzkiego Sądu Administracyjnego we Wrocławiu. Sąd uwzględnił skargę wojewody i stwierdził nieważność kwestionowanych przepisów uchwały regulujących odpowiedzialność zarządców nieruchomości za wielkość szyldów umieszczanych na elewacji (pominięcie innych podmiotów mogących władać nieruchomością) oraz tych odnoszących się do obowiązku usunięcia z elewacji uszkodzeń, zabrudzeń czy ogłoszeń w terminie do dwóch miesięcy od ich powstania73. Orzeczenie jest nieprawomocne.

Park Kulturowy "Stare Miasto" we Wrocławiu obejmuje swoim obszarem około 210 ha (ponad dwukrotnie więcej niż Park Kulturowy Stare Miasto w Krakowie utworzony cztery lata wcześniej). Jest drugim po Krakowie parkiem kulturowym kompleksowo porządkującym przestrzeń miejską. w § 3 uchwały wskazano cele utworzenia parku

Miasto. Pamięć i Przyszłość 1 (2016) ISSN 2543-621X 99 i instrumenty, za pomocą których będą osiągane. Wśród pierwszych wymieniono: zachowanie i odtwarzanie historycznych układów urbanistycznych i obiektów zabytkowych, a także ich uzupełnianie i wzbogacanie, zapewnienie ekspozycji zabytków nieruchomych i historycznych zespołów budowlanych oraz trójwymiarowej sylwety miasta, rewaloryzowanie i rewitalizowanie przestrzeni miejskiej, ograniczenie niekorzystnego wpływu nośników reklamowych na przestrzeń publiczną. Instrumentami służącymi realizacji tych celów są: sporządzanie miejscowych planów zagospodarowania przestrzennego, sporządzenie planu ochrony parku kulturowego oraz wprowadzenie zakazów i ograniczeń na obszarze parku.

Katalog zakazów i ograniczeń ustalonych dla obszaru parku wskazany w uchwale różni się nieco od tych zawartych w jej projekcie ${ }^{74}$. Przede wszystkim w niewielkim stopniu uregulowano kwestie dotyczące prowadzenia robót budowlanych (w projekcie ujęto je w osobnym rozdziale, a ostatecznie ich część znalazła się w rozdziale poświęconym zmianie sposobu korzystania z zabytków nieruchomych na terenie parku). W tym aspekcie unormowania przyjęte dla wrocławskiego parku kulturowego istotnie różnią się od tych przyjętych dla parku w Krakowie, gdzie przepisy

\section{Ibidem, s. 2.}

72. Uchwała Nr LVI/1465/14 Rady Miejskiej Wrocławia z dnia 10 kwietnia 2014 r. w sprawie utworzenia parku kulturowego "Stare Miasto" (Dz. Urz. Woj. Dolnośląskiego z 2014 r. poz. 2049).

73. Wyrok WSA we Wrocławiu z dnia 15 marca 2015r., IV SA/Wr 745/14.

74. Projekt uchwały Rady Miejskiej Wrocławia w sprawie utworzenia parku kulturowego pod nazwą "Park Kulturowy "Stare Miasto”, załącznik do Uchwały nr L/1263/13 Rady Miejskiej Wrocławia z dnia 28 listopada 2013 r. w sprawie konsultacji projektu uchwały w sprawie utworzenia parku kulturowego pod nazwą "Park Kulturowy Stare Miasto", http://uchwaly.um.wroc.pl/uchwala.aspx?numer=L/1263/13 (dostęp: 22 VIII 2016 r.). 
te stały się ważnym instrumentem ochrony ${ }^{75}$. We Wrocławiu najważniejsze zakazy i ograniczenia odnoszą się do handlu i gastronomii, działań reklamowych oraz zmiany sposobu korzystania z obiektów zabytkowych. Na obszarze parku zabrania się handlu i działalności gastronomicznej poza budynkami oraz w przejściach i przejazdach bramowych, a wyjątkami są: handel stanowiący część zorganizowanych imprez, handel niektórymi towarami (pamiątki, książki, owoce i warzywa), działalność gastronomiczna na Wyspie Słodowej, części placu Nowy Targ czy w ogródkach gastronomicznych (§ 4 pkt 1 i 2).

Znacznie obszerniejszy katalog ograniczeń i zakazów dotyczy działań reklamowych. Jak wskazywano w uzasadnieniu do projektu, przestrzeń Starego Miasta stała się obiektem agresywnych działań reklamowych prowadzonych w wielu formach, a skutkujących nadmierną ingerencją w krajobraz ${ }^{76}$. Dlatego uchwała:

- nie dopuszcza, poza kilkoma wyjątkami (szyldy, menu restauracji), organizowania na obszarze parku wydarzeń służących celom reklamowym,

- nie dopuszcza działań reklamowych na budynkach,

- nie dopuszcza przyklejania i mocowania reklam do okien i witryn, działań reklamowych po wewnętrznej stronie witryn, przy czym ich przeszklenia powinny być przezroczyste (ten zapis stał się przedmiotem skargi do WSA),

- zakazuje stosowania bannerów,

75. Por. § 4 Uchwały nr CXV/1547/10 Rady Miasta Krakowa.

76. Uzasadnienie..., s. 7.

77. Oficjalna strona Parku Kulturowego Stare Miasto: http://www. wroclaw.pl/park-kulturowy-wroclaw. Dyskusja o zmianach wprowadzanych uchwałą o utworzeniu parku, m.in.: B. Maciejewska, Szpetne reklamy i graffiti nie będa już bezkarne, "Gazeta Wyborcza” [wyd. Wrocław], 24 III 2014, M. Kokoszkiewicz, Koniec z reklamami w centrum. Dziś wchodza przepisy parku kulturowego, "Gazeta
- zakazuje używania wolno stojących nośników reklamowych (poza słupami reklamowymi, stojakami z menu i informacją o działaniach instytucji kultury).

Nawet dopuszczone uchwałą formy działań reklamowych podlegają ograniczeniom - szyldy lub nośniki reklamowe zawierające menu nie mogą zajmować więcej niż 4\% ściany (§ 8 pkt 2). Zastanawiać może natomiast zrównanie lokali gastronomicznych i instytucji kultury, które mają możliwość ustawienia jednego stojaka informacyjnego. Na terenie parku zakazano ponadto ustawiania pojazdów z przymocowanymi nośnikami reklamowymi, umieszczania takich nośników na obiektach pływających, na nawierzchni jezdni, chodników i ścieżek rowerowych oraz obnoszenia reklam i ich rozdawania poza budynkami. Osobny paragraf poświęcono reklamom na rusztowaniach, wskazując, że mogą one obejmować do 1/3 całkowitej powierzchni materiału pokrywającego rusztowanie (pozostałą część powinno zajmować odwzorowanie remontowanej elewacji) przez okres nie dłuższy niż 12 miesięcy. Te przepisy spotykały się z dużą aprobatą mieszkańców, a zmiany, jakie przyniosły, są na bieżąco prezentowane na stronie parku i łamach lokalnej prasy ${ }^{77}$.

Mając na uwadze, że dostosowanie się do nowych przepisów może wymagać szeregu działań, ustalono dla właścicieli, zarządców nieruchomości oraz użytkowników obiektów położonych na obszarze parku 12-miesięczny okres na dokonanie koniecznych zmian. Przepisy § 4-21 weszły w życie 12 miesięcy od ogłoszenia

Miasto. Pamięć i Przyszłość 1 (2016) ISSN 2543-621X 
uchwały w wojewódzkim dzienniku urzędowym.

Realizując obowiązki wynikające z uchwały o utworzeniu parku, w październiku 2014 r. powołano Grupę Doradczą i zespół roboczy ds. Parku Kulturowego "Stare Miasto”, w skład których weszli m.in. wiceprezydent Wrocławia, miejski konserwator zabytków, urzędnicy wydziałów architektury i budownictwa, kultury, rozwoju gospodarczego, inżynierii miejskiej, komunikacji społecznej czy wydziału prawnego, a także przedstawiciele Straży Miejskiej Wrocławia czy Zarządu Zasobu Komunalnego ${ }^{78}$. Zgodnie z § 3 zarządzenia Prezydenta Wrocławia do zadań Grupy Doradczej należy: przygotowanie procedur i koordynowanie działań mających na celu sprawne wdrożenie przepisów dotyczących Parku Kulturowego "Stare Miasto", zapewnienie przestrzegania przepisów prawa na terenie parku, opracowanie kampanii informacyjnej, koordynowanie prac i nadzór nad opracowaniem planu ochrony parku, ustalanie harmonogramu działań, analiza i ocena skutków uchwały o utworzeniu Parku Kulturowego "Stare Miasto", opiniowanie wniosków o zmianę przepisów uchwały.

Jednocześnie trwają bieżące prace nad przygotowaniem miejscowych planów zagospodarowania przestrzennego, w tym także dla części terenów objętych Parkiem Kulturowym Stare Miasto. Jednak najistotniejsze znaczenie dla funkcjonowania parku będzie miało opracowanie planu ochrony parku kulturowego. Plan zawierać powinien m.in.: syntetyczny zestaw obiektów kulturowych, w tym zabytków ujętych

Miasto. Pamięć i Przyszłość 1 (2016) ISSN 2543-621X 101 w rejestrze i ewidencji zabytków, obszarów wskazanych do ochrony, dominant krajobrazowych czy obiektów stanowiących tło „przyrodnicze”; zestaw rozmieszczenia elementów stanu zagospodarowania i przesądzeń planistycznych oraz granic istniejącego zainwestowania, analizę uwarunkowań planistycznych, własnościowych i formalno-prawnych ${ }^{79}$. Prócz diagnozy reprezentatywnych cech krajobrazu kulturowego i analizy przewidywanej i pożądanej zmiany w przyszłości najważniejszą część planu stanowią ustalenia i wytyczne co do ustalenia granic i stref, kierunków i zakresów działań w poszczególnych strefach, sposobów rozwiązywania konfliktów i ograniczania zagrożeń oraz wytyczne do miejscowego planu zagospodarowania ${ }^{80}$. Plan traktować należy jako narzędzie wspierające dla planu miejscowego, motywujące do uszczegółowienia jego zapisów w zakresie ochrony, precyzujące zasady gospodarowania poprzez ustalenie specjalnych reguł stosowanych na terenach o wyjątkowych wartościach kulturowych i przyrodniczych ${ }^{81}$.

Warto w tym miejscu wskazać, że plan ochrony Parku Kulturowego „Stare Miasto” powstaje w nowych uwarunkowaniach prawnych, które uległy modyfikacji po przyjęciu tzw. ustawy krajobrazowej. Zarówno zmiana definicji krajobrazu, wprowadzenie nowej jego kategorii, czyli krajobrazu priorytetowego, projektowana

Wyborcza" [wyd. Wrocław], 23 IV 2015.

78. Zarządzenie nr 12360/14 Prezydenta Wrocławia z 30 października 2014 r. w sprawie powołania Grupy Doradczej i Zespołu Roboczego ds. Parku Kulturowego "Stare Miasto", http://uchwaly. um.wroc.pl/uchwala.aspx?numer=12360/14 (dostęp: 22 VIII 2016 r.).

79. Zasady tworzenia Parku Kulturowego..., s. 12.

80. Ibidem, s. 13.

81. Plan ochrony Parku Kulturowego Stare Miasto w Krakowie, s. 3. 
zmiana statusu prawnego planów ochrony parków krajobrazowych jak i nadanie nowych kompetencji samorządom województw mogą wpłynąć na konstruowanie planów ochrony parków kulturowych.

\section{Przyszłość parków kulturowych} z perspektywy ustawy krajobrazowej

We wrześniu 2015 r. weszła w życie przywoływana już ustawa o zmianie niektórych ustaw w związku ze wzmocnieniem narzędzi ochrony krajobrazu, nazywana ustawą krajobrazową. Akt ten daje gminom możliwość ustalenia zasad i warunków sytuowania obiektów małej architektury, tablic i urządzeń reklamowych oraz ogrodzeń połączoną z prawem do pobierania nowej opłaty, tj. opłaty reklamowej. Część nowych rozwiązań dotyczy sfer, które gminy regulować mogły właśnie na drodze powoływania do życia parków kulturowych. Trzeba w tym miejscu zaznaczyć, że ustawa nie posiada kompleksowego charakteru, a obrany przez ustawodawcę kierunek doprowadzić może do zwiększania chaosu zamiast do uporządkowania regulacji w tym obszarze ${ }^{82}$.

Nowelizując ustawę o planowaniu i zagospodarowaniu przestrzennym, ustawa krajobrazowa wprowadziła możliwość przyjęcia przez radę gminy uchwały w sprawie zasad sytuowania obiektów małej architektury, tablic i urządzeń reklamowych oraz ogrodzeń, czyli tzw. uchwały krajobrazoweje3. Najważniejszym aspektem są bez wątpienia uprawnienia związane z wpływem na rozmiary i charakter reklam w gminie. W tej kwestii gminy uzyskały bardzo dużą swobodę - włącznie z całkowitym zakazem umieszczania tablic i urządzeń reklamowych, przy czym uchwała w tej sprawie musi uwzględniać ochronę zabytków nieruchomych wpisanych do rejestru (z ich otoczeniem), ochronę zabytków wpisanych do ewidencji gminnej i wnioski i rekomendacje z audytów krajobrazowych. Uchwała krajobrazowa może przewidywać także różne strefy ochrony dla konkretnych obszarów gminy. Ustalono również 12-miesięczny okres na dostosowanie się do nowych zakazów oraz warunków zasad w niej określonych (art. 37a). Oznacza to, że gminy uzyskały obecnie narzędzie o podobnym charakterze do tego zawartego w regulacjach dotyczących parków kulturowych. Zasadnicza różnica odnosi się do możliwości wprowadzenia opłaty reklamowej od umieszczanych na terenie gminy tablic i urządzeń reklamowych. Ustawa krajobrazowa znowelizowała bowiem ustawę o podatkach i opłatach lokalnych ${ }^{84}$. Opłata reklamowa, składająca się z części stałej i zmiennej, może być pobierana na obszarach, dla których przyjęto uchwałę krajobrazową (art. 17a ust. 1 i 2 oraz 17b ust. 1). Z wprowadzeniem opłaty związana jest także możliwość wymierzenia decyzją wójta (burmistrza, prezydenta miasta) kary pieniężnej za umieszczanie reklam niezgodnie z podjętą uchwałą. Podsumowując, uchwalenie uchwały krajobrazowej jest zadaniem fakultatywnym gminy, a motywacją do działań porządkujących przestrzeń publiczną ma być możliwość uzyskania przez samorząd gminny dodatkowych dochodów. Ale trudno jednoznacznie

82. Por. D. Kostrzewa, op. cit., s. 61.

83. Jak wykorzystać potencjał "ustawy krajobrazowej”, s. 10.

84. Ustawa z dnia 12 stycznia 1991 r. o podatkach i opłatach lokalnych (tekst jedn. Dz. U. z 2016 r., poz. 716).

Miasto. Pamięć i Przyszłość 1 (2016) ISSN 2543-621X 
przesądzić, czy podniesie to standardy w zakresie ochrony krajobrazu ${ }^{85}$.

Druga grupa zagadnień regulowanych ustawą krajobrazową, a mających wpływ na funkcjonowanie parków kulturowych, związana jest z audytem krajobrazowym. Zgodnie z art. 38a znowelizowanej ustawy o planowaniu i zagospodarowaniu przestrzennym nie rzadziej niż raz na dwadzieścia lat sporządza się dla obszaru województwa audyt krajobrazowy identyfikujący krajobrazy występujące na obszarze województwa z określeniem ich cech charakterystycznych i oceny ich wartości. Audyt określa w szczególności krajobrazy występujące na terenie województwa i lokalizację krajobrazów priorytetowych oraz wskazuje lokalizację i granice: parków kulturowych, parków narodowych, rezerwatów przyrody, parków krajobrazowych czy obiektów z listy Światowego Dziedzictwa UNESCO. Krajobraz priorytetowy to nowa kategoria obejmująca sobą krajobraz szczególnie cenny dla społeczeństwa ze względu na swoje wartości przyrodnicze, kulturowe, historyczne, architektoniczne, urbanistyczne, ruralistyczne lub estetyczno-widokowe, wymagające zachowania lub określenia zasad lub warunków jego kształtowania. Ustawa nie przewiduje szczególnych form ochrony tych krajobrazów, ale być może właśnie formuła parku kulturowego nadaje się do ochrony niektórych krajobrazów uznanych za priorytetowe.

Sporządzenie audytu jest zadaniem samorządu województwa, które powinno być zrealizowane w ciągu trzech lat od daty wejścia w życie ustawy krajobrazowej. Ten aspekt nowych

Miasto. Pamięć i Przyszłość 1 (2016) ISSN 2543-621X 103 regulacji jest najbardziej dyskutowany, gdyż ingeruje w samodzielność gmin, nie respektując m.in. zasady subsydiarności, wskazanej w Europejskiej Konwencji Krajobrazowej, jako istotnej zasady kształtowania polityki ochrony krajobrazu. Ustawa zakłada jednak zasięgnięcie opinii o projekcie audytu rad gmin położonych na terenie województwa.

Jedną z wielu niejasności pojawiających się po wejściu w życie ustawy krajobrazowej jest także status planów ochrony. Ustawa wyraźnie wskazuje, że zgodnie z nowym brzmieniem art. 19 ust 4a ustawy o ochronie przyrody plan ochrony parku krajobrazowego jest aktem prawa miejscowego ${ }^{86}$. Do tej pory plany te, podobnie jak plany ochrony parków kulturowych nie miały, charakteru powszechnie obowiązującego. Choć wydaje się, że intencją ustawodawcy było zbliżenie tych dwóch instytucji prawnych do siebie, to nastąpi istotne rozróżnienie ich znaczenia.

Podsumowując, jeśli główną motywacją do tworzenia parku kulturowego jest chęć ograniczenia chaosu przestrzennego wywołanego nadmiarem reklam, nowe regulacje ustawy krajobrazowej mogą okazać się skuteczniejsze i spowodować, że samorząd gminny ograniczy się do uchwalenia uchwały krajobrazowej zamiast wdrożenia bardziej kompleksowego planu ochrony krajobrazu w postaci parku kulturowego. Ustawa daje nie tylko szansę ograniczenia czy wręcz wyeliminowania reklam na części obszaru gminy, ale także możliwość nałożenia kary na podmioty nierealizujące jej zapisów. Dodatkowo

85. Ustawa krajobrazowa - czyli zmiany w zasadach umieszczania reklamy w krajobrazie, https://biuletyn.piszcz.pl/prawo-administracyjne/593-ustawa-krajobrazowa-czyli-zmiany-w-zasadach-umieszczania-reklamy-w-krajobrazie (dostęp: 25 VIII 2016r.).

86. Ustawa z dnia 16 kwietnia 2004 r. o ochronie przyrody (tekst jedn. Dz. U. z 2015 r., poz. 1654 z późn. zm.). 
ustanawia nowe źródło dochodów, co przy sytuacji finansowej jednostek samorządu terytorialnego, może motywować je do ustanawiania ograniczeń w tej sferze. Natomiast przepis o wskazywaniu przez samorząd województwa w audycie krajobrazowym granic i lokalizacji parków kulturowych nie będzie zapewne służył jedynie ich ewidencji. Być może odegrają one większą rolę w procesie ich tworzenia przez szczegółowe rekomendacje i wdrażanie mechanizmów zachęcających gminy do tworzenia parków na swoim obszarze. Kształt dotychczasowych unormowań nie przyczyniał się do skutecznej ochrony krajobrazu i nie motywował jednostek samorządu do bardziej aktywnych działań, jednak wydaje się, że ustawa krajobrazowa ani nie zwiększy w istotnym stopniu skuteczności instrumentów ochrony krajobrazu, ani nie wpłynie w widoczny sposób na dynamikę tworzenia nowych parków kulturowych.
Agnieszka Pawłowska absolwentka UWr na kierunku polonistyka i politologia, doktor nauk humanistycznych w zakresie nauk o polityce (2008). Naukowo zwiq̨ana z Dolnośląską Szkołą Wyższa, gdzie pracuje jako adiunkt w Zakładzie Administracji i Polityki Społecznej w Instytucie Bezpieczeństwa i Spraw Międzynarodowych. Zainteresowania badawcze dotycza: polityki społecznej jst, bezpieczeństwa społecznego, kapitału społecznego w Polsce, systemu pomocy społecznej w Polsce. 


\section{Bibliografia:}

\section{Ustawy}

Konstytucja RP z dnia 12 kwietnia 1997 r., (Dz.U. Nr 78, poz. 483 z późn zm.).

Ustawa z dnia 12 stycznia 1991 r. o podatkach i opłatach lokalnych, (tekst jedn. Dz.U. z 2016 r. poz. 716). Ustawa z dnia 8 marca 1990 r. o samorządzie gminnym, (Dz.U. z 2016 r. poz. 446).

Ustawa z dnia 23 marca 2003 r. o planowaniu i zagospodarowaniu przestrzennym, (Dz.U.

z 2016 r. poz. 778)

Ustawa z dnia 16 kwietnia 2004 r. o ochronie przyrody, (tekst jedn. Dz.U. z 2015 r. poz. 1654 z późn. zm.) Ustawa z dnia 24 kwietnia 2015 r. o zmianie niektórych ustaw w związku ze wzmocnieniem narzędzi ochrony krajobrazu, (Dz.U. poz. 774, z późn. zm.)

Ustawa z dnia 23 lipca 2003 r. o ochronie zabytków i opiece nad zabytkami, (Dz.U. z 2014 r. poz. 1446, z późn. zm.)

\section{Ratyfikowane umowy międzynarodowe} Europejska Karta Samorządu Lokalnego, (Dz. U. z 1994, Nr 124, poz. 607)

Europejska Konwencja Krajobrazowa sporządzona we Florencji 20 października 2000 r., (Dz. U. z 2004 r. Nr 14, poz. 98)

Konwencja w sprawie ochrony światowego dziedzictwa kulturalnego i naturalnego, przyjęta w Paryżu dnia 16 listopada 1972 r. przez Konferencję Generalną Organizacji Narodów Zjednoczonych dla Wychowania, Nauki i Kultury na jej siedemnastej sesji. (Dz.U. z 1976 r. Nr 190, poz. 32.)

\section{Akty wykonawcze}

Rozporządzenie Prezydenta RP z dnia 20 września 2011 r. w sprawie uznania za pomnik historii „Pałace i parki krajobrazowe Kotliny Jeleniogórskiej", Dz. U. nr 217, poz.1283.

\section{Uchwały}

Uchwała nr CXIV/1174/06 Rady Miasta Krakowa z dnia 6 lipca 2006 r. w sprawie utworzenia parku kulturowego pod nazwą „Zwierzyniecki Park Kulturowy", (Dz. Urz. Woj. Małopolskiego z 2006 r. Nr 427, poz. 2710).

Uchwała Zgromadzenia Związku Gmin Karkonoskich nr 48/ XVII/09 z dnia 30 stycznia 2009 r. w sprawie utworzenia parku kulturowego pod nazwą „Park Kulturowy Kotliny Jeleniogórskiej”, (Dz. Urz. Woj. Dolnośląskiego z 2009 r. Nr 42, poz. 890 z późn. zm.).

Uchwała nr CXV/1547/10 Rady Miasta Krakowa z dnia 3 listopada 2010 r . w sprawie utworzenia parku kulturowego pod nazwą Park Kulturowy Stare Miasto, (Dz. Urz. Woj. Małopolskiego z 2010 r. Nr 647, poz. 5336).

Uchwała Nr LVI/1465/14 Rady Miejskiej Wrocławia z dnia 10 kwietnia 2014 r. w sprawie utworzenia parku kulturowego „Stare Miasto”, (Dz. Urz. Woj. Dolnośląskiego z 2014 r. poz. 2049). Uchwała nr 15/59/14 Zarządu Związku Gmin Karkonoskich z dnia 25 września 2014 r. w sprawie ustalenia procedury koniecznej do likwidacji Parku Kulturowego pod nazwą Park Kulturowy Kotliny Jeleniogórskiej, http://www.zgkkarkonosze.pl/bip/ pliki/uchawly/2014/Zarzad_115_59_14.pdf (dostęp: 24 VII 2016 r.).

Uchwała nr LVI/349/14 Rady Gminy Mysłakowice z dnia 12 listopada 2014 r. w sprawie uchylenia uchwały nr 111/XVIII/2008 Rady Gminy Mysłakowice z dnia 28 marca 2008 r. w sprawie zaopiniowania projektu utworzenia parku kulturowego 
pod nazwą Park Kulturowy Kotliny Jeleniogórskiej, http://myslakowice.bip.net.pl/p=document\&action=save\&id=3644\&bar_id=4437 (dostęp: 24 VII 2016 r.). Uchwała nr XII/183/2015 Rady Miasta Zakopane z dnia 3 września 2015 r. w sprawie utworzenia parku kulturowego pod nazwą „Park Kulturowy obszaru ulicy Krupówki”, nie została opublikowana w Dzienniku Urzędowym Województwa Małopolskiego. http://bip.zakopane.eu/zalacznik/17563 , (dostęp: 17 VIII 2016 r.)

\section{Akty wewnętrzne kierownika jednostki}

Zarządzenie nr 12360/14 Prezydenta Wrocławia z 30 października 2014 r. w sprawie powołania Grupy Doradczej i Zespołu Roboczego ds. Parku Kulturowego "Stare Miasto", http://uchwaly. um.wroc.pl/uchwala.aspx?numer=12360/14 (dostęp: 22 VIII 2016 r.).

\section{Wyroki i orzeczenia sądów administracyjnych}

Wyrok WSA w Krakowie z dnia 3 kwietnia 2007 r. III SA/Kr 55/07.

Wyrok NSA z 4 kwietnia 2007 r., II OSK 7/07. Wyrok WSA we Wrocławiu z dnia 15 marca 2015 r., IV SA/Wr 745/14

\section{Projekty, programy i plany}

Plan ochrony Fortecznego Parku Kulturowego w Srebrnej Górze, http://stoszowice.pl/download/ File/pliki_pdf/Plan_Ochrony_Parku.pdf (dostęp: 26 VIII 2016 r.).
Plan ochrony Parku Kulturowego Stare Miasto w Krakowie, przyjęty uchwałą nr XLII/544/12 Rady Miasta Krakowa z dnia 4 kwietnia 2012 r. https:// www.bip.krakow.pl/_inc/rada/uchwaly/show_pdf. php?id=62701 (dostęp: 18 VIII 2016 r.).

Program opieki nad zabytkami województwa dolnośląskiego na lata 2015-2018, http://www.umwd. dolnyslask.pl/fileadmin/user_upload/Biuro_Prasowe/Grudzien_2014/Program_Zabytki.pdf (dostęp: 17 VIII 2016 r.)

Projekt uchwały Rady Miejskiej Wrocławia w sprawie utworzenia parku kulturowego pod nazwą „Park Kulturowy „Stare Miasto”, załącznik do Uchwały nr L/1263/13 Rady Miejskiej Wrocławia z dnia 28 listopada 2013 r. w sprawie konsultacji projektu uchwały w sprawie utworzenia parku kulturowego pod nazwą „Park Kulturowy Stare Miasto", http://uchwaly.um.wroc.pl/uchwala.aspx?numer=L/1263/13 (dostęp: 22 VIII 2016 r.). Projekt ustawy o zmianie niektórych ustaw z związku ze wzmocnieniem narzędzi ochrony krajobrazu. Uzasadnienie, Druk Sejmowy nr 1525, http://orka.sejm.gov.pl/Druki7ka.nsf/0/ EOEC31AF25E44523C1257BA4002A90F4/\%24File/1525.pdf (dostęp: 11 VIII 2016 r.) Ustawa krajobrazowa - czyli zmiany w zasadach umieszczania reklamy w krajobrazie, https://biuletyn.piszcz.pl/prawo-administracyjne/593-ustawa-krajobrazowa-czyli-zmiany-wzasadach-umieszczania-reklamy-w-krajobrazie (dostęp: 25 VIII 2016 r.).

\section{Publikacje}

Konwencje UNESCO w dziedzinie kultury, red. 
K. Zalasińska, Warszawa 2014.

Kostrzewa D., Ochrona dziedzictwa kulturowego i naturalnego. Perspektywa prawna i kryminologiczna, red. W. Pływaczewski, B. Gadecki, Warszawa 2015. Leksykon prawa ochrony zabytków, red. K. Zeidler, Warszawa 2010.

Łuczyński R. M., Migoń P., Napierała P., Krajobraz kulturowy regionu Kotliny Jeleniogórskiej, Wrocław 2015. Michalak A., Ginter A., Ustawa o ochronie zabytków i opiece nad zabytkami, Warszawa 2016.

Pruszyński J., Dziedzictwo kultury Polski. Jego straty i ochrona prawna, T. 1, Zakamycze 2001.

Pruszyński J., Dziedzictwo kultury Polski, T. 2.

Przyborowska-Klimczak A., Rozwój ochrony dziedzictwa kulturalnego w prawie międzynarodowym na przełomie XX i XXI wieku, Lublin 2011.

Raport na temat funkcjonowania systemu ochrony dziedzictwa kulturowego w Polsce po roku 1989, red. J. Purchla, Warszawa 2009.

Rouba M., Zadania władz publicznych w zakresie ochrony i opieki nad zabytkami w Rzeczpospolitej Polskiej, Toruń 2013.

Zalasińska K., Ochrona zabytków, Warszawa 2010. Zeidler K., Prawo ochrony dziedzictwa kultury, Warszawa 2007.

\section{Źródła internetowe}

Jak wykorzystać potencjał "ustawy krajobrazowej”. Instrumenty prawne i propozycje. Przewodnik dla samorzadu gminnego, Gdańsk, http://www.im.edu.pl/ wpcontent/uploads/2011/06/20160302_podrecznik.pdf (dostęp: 10 VIII 2016 r.)

Korzeń K., Park Kulturowy Kotliny Jeleniogórskiej. „Dolina Pałaców i Ogrodów", http://www.karkonosze. eu/files/park-kulturowy/09-KK-Konc.PKKJ.pdf (dostęp: 24 VII 2016)

Korzeń K., Park Kulturowy Kotliny Jeleniogórskiej, „Urbanista” nr 11/2008, http://www.dolinapalacow.pl/
zdjecia/2008_11-Park-Kulturowy_Kotliny_Jeleniogorskiej\%20-Urbanista.pdf (dostęp: 25 VII 2008 r.) http://podhale24.pl/aktualnosci/artykul/42637/ Park_Kulturowy_Kotliny_Zakopianskiej_do_likwidacji.html (dostęp: 23 VII 2016 r.) Lista parków kulturowych - stan na 31 grudnia 2015, http://www.nid.pl/informacje_ogolne/Zabytki_w_Polsce/Parki_kulturowe/Zestawienie_parkow/ miejsce.php?ID=30 (dostęp: 17 VIII 2016 r.)

Oficjalna strona Parku Kulturowego Stare Miasto: http://www. wroclaw.pl/park-kulturowy-wroclaw. Dyskusja o zmianach wprowadzanych uchwałą o utworzeniu parku, m.in.: B. Maciejewska, Szpetne reklamy i graffiti nie będa już bezkarne, "Gazeta Wyborcza" [wyd. Wrocław], 24 III 2014, M. Kokoszkiewicz, Koniec z reklamami w centrum. Dziś wchodza przepisy parku kulturowego, "Gazeta Wyborcza” [wyd. Wrocław], 23 IV 2015.

Rekomendacja UNESCO w sprawie historycznego krajobrazu miejskiego z dnia 10 listopada 2011 r., http://www.unesco.pl/ fileadmin/user_upload/pdf/ Rekomendacje/rekomenkrajobraz.pdf (dostęp: 24 VII 2016 r.)

Uzasadnienie, http://www.wroclaw.pl/files/urzad/ konsultacje\%20spoleczne/uzasadnienie.pdf (odczyt: 10 VIII 2016 r.)

Zalecenia UNESCO w sprawie historycznego krajobrazu miejskiego 2011, http://www.unesco.pl/ fileadmin/user_upload/pdf/Rekomendacje/Zalecenie_w_sprawie_krajobrazu_miejskiego.pdf (dostęp: 14 VIII 2016)

Zasady tworzenia Parku Kulturowego, zarządzania nim oraz sporządzania planu jego ochrony, http://www.nid.pl/pl/Informacje_ogolne/Zabytki_w_ Polsce/Parki_kulturowe/Zasady\%20tworzenia\%20 Parku\%20Kulturowego,\%20zarz\%C4\%85dzania\%20nim\%20oraz\%20sporz\%C4\%85dzania\%20 planu\%20jego\%20ochrony.pdf (dostęp: 24 VII 2016 r.). 